\title{
Penerapan Teknologi Pendeteksi Kebocoran Liquified Petrolium Gas Berperingatan Alarm dan SMS
}

\section{Implementation Leakge Detection Technology of Liquified Petroleum Gas Warning Alarm and SMS}

\author{
Guntoro Barovih $^{* 1}$, R. Ardianto ${ }^{2}$, Septa Itong Siregar ${ }^{3}$, Septa Pratama ${ }^{4}$ \\ ${ }^{1,2,3,4}$ Prodi Teknik Informatika, Jl. Basuki Rahmat No. 5, Palembang \\ STMIK PALCOMTECH Palembang. \\ *guntorobarovih@gmail.com, ardianto@gmail.com, septaitong@gmail.com, \\ septapratama@gmail.com
}

\begin{abstract}
Abstrak
Menurut data pusat studi kebijakan publik (Puskepi) sejak 2008 hingga 2010 di indonesia terjadi 189 kali kasus ledakan dalam pemakaian tabung gas rumah tangga, dimana tahun 2008 terjadi 61 kasus, tahun 2009 turun menjadi 50 kasus, kemudian meningkat di tahun 2010 sebanyak 78 kasus. Kebocoran Liquidfied petrolium gas (LPG) tidak hanya menyebabkan ledakan tetapi juga kebakaran, Lambatnya antisipasi terjadinya kebocoran dikarenakan tidak adanya peringatan dini yang diberikan kecuali bau gas yang menyengat sehingga kebakaran tidak terelakkan. Untuk itu dibangunlah suatu sistem yang dapat mendeteksi kebocoran LPG yang dikontrol oleh ATMEGA 16, dimana sensor yang digunakan MQ6 untuk mendeteksi gas metan dan MQ5 untuk mendeteksi asap, kemudian peringatan dini kebocoran gas dikirimkan ke pesan singkat dan alarm sebagai notifikasi sistem ke pengguna. Sistem yang dibangun menggunakan metode SDLC serta menggunakan pengujian blackbox dan bersifat peringatan bukan penanganan. Dari hasil pengujian jarak ideal pengujian sensor deteksi kebocoran gas yaitu 0,5 meter 555ppm dengan waktu 10 detik dan 0,5 meter 224 ppm dengan waktu 15 detik pada pengujian sensor asap di ruang berfentilasi dan deteksi kebocaoran gas 0,5 meter 580ppm dengan waktu 10 detik, dan deteksi asap 0,5 meter 175 ppm dengan waktu 13 detik di ruang kedap udara.
\end{abstract}

Kata kunci : Alarm, ATMEGA 16, sensor MQ6, kebocoran gas, Liquified Petrolium Gas

\begin{abstract}
According to the data center for the study of public policy (Puskepi) from 2008 to 2010 in indonesia occurred in the blast case time 189 discharging household gas cylinders, in 2008 happened 61 cases, in 2009 dropped to 50 cases, then in 2010 by as much as 78 cases. Liquidfied petroleum gas leakage ( $L P G)$ is not only causing an explosion but also fire, the slowness of the anticipation of the occurrence of leaks due to the lack of early warning is given except for the smell of gas that stung so fires are not inevitable. To that end, a system which can detect leaks of LPG, which is controlled by the ATMEGA 16, where sensors are used to detect methane gas MQ6 and MQ5 to detect smoke, gas leak early warning and then sent to a short message and alarm notification system as to the user. The system is built using methods of SDLC, use blackbox testing and exhortative not handling. From the results of testing distance ideal testing sensors detect gas leaks is 0.5 meters 555ppm with a time of 10 seconds and $0.5 \mathrm{ft} 224 \mathrm{ppm}$ with 15 seconds on testing smoke sensor in the space berfentilasi and gas leaks detection $0.5 \mathrm{ft} 580 \mathrm{ppm}$ with a time of 10 seconds, and smoke detection 0.5 meter $175 \mathrm{ppm}$ with a time of 13 minutes in the airtight space.
\end{abstract}

Keywords : Alarm, ATMEGA 16, MQ6 sensor, gas leak, Liquified Petrolium Gas

\section{PENDAHULUAN}

Liquified Petrolium Gas (LPG) merupakan gas minyak bumi yang dicairkan yang mengandung campuran hidrokarbon yang kemudian dimampatkan dengan penambahan tekanan guna penurunan suhunya kemudian berubah menjadi cair. LPG didominasi oleh propana dan 
butana. Dalam kondisi atmosfer LPG berubah menjadi bentuk gas[1]. Oleh karena itu LPG dipasarkan dalam bentuk cair yang dimasukkan ke dalam tabung logam bertekanan. Bahan bakar jenis LPG ini banyak digunakan sebagai bahan bakar alat dapur. Bahan bakar jenis ini memiliki resiko lebih tinggi jika dibandingkan dengan bahan bakar cair seperti minyak tanah sebagai bahan bakar alat dapur.

Salah satu resiko yang dihasilkan dari LPG adalah ledakan dan kebakaran jika terjadi kebocoran pada instalasi gas mapun pada tabung kemasan gas LPG. Berdasarkan data Pusat Studi Kebijakan publik (Puskepi) sejak 2008 sampai 2010 di Indonesia terjadi sebanyak 189 kasus ledakan dalam pemakaian tabung gas rumah tangga, di tahun 2008 terjadi 61 kasus, di thun 2009 turun menjadi 50 kasus, kemudian meningkat di tahun 2010 sebanyak 78 kasus ledakan[2]. Dan tiap tahun selalu terjadi kasus ledakan dan pada tahun 2014 ini terjadi ledakan tabung gas yang merenggut 12 korban luka bakar serius[3].

Ledakan ataupun kebakaran bisa cepat terjadi dikarenakan pada saat gas memasuki ruang terbuka dengan tekanan yang lebih rendah, maka gas cair akan berubah menjadi gas yang bisa memuai dan berubah volume menjadi lebih besar. Jika hal ini tidak diketahui, maka akan mudah memercikkan api dan terjadi kebakaran. Kebakaran akibat kebocoran LPG bisa terjadi jika terpicu oleh percikan api baik yang disengaja oleh pengguna ataupun oleh komponen elektronik yang tetap menyala pada saat terjadi kebocoran gas yang tidak diketahui. Jika kebakaran ini terjadi tidak jarang banyak menimbulkan kerugian-kerugian, baik kerugian materi mapun kerugian pada korban jiwa.

Untuk mengurangi resiko terjadiknya kerugian materi dan korban jiwa, maka diperlukan suatu sistem pendeteksi kebocoran gas yang nantinya dapat dijadikan sebagai sistem pengaman atau peringatan dini terhadap kebocoran gas. Dengan adanya sistem peringatan dini ini diharapkan pengguna yang bersangkutan dapat memberikan respon cepat terhadap kebocoran gas yang ada pada lingkungannya sendiri. Peringatan yang dikirimkan ke pengguna berupa pesan singkat dan alarm yang dapat memberikan peringatan ke pada pengguna.

Fauziah dan Subali [4] dihasilkan alat akan bekerja apabila sensor figarro TGS 2610 untuk mendeteksi adanya kebocoran gas maka ic ISD 2560 akan mengeluarkan hasil rekaman suara melalui speaker dan secara bersamaan fan akan berputar sampai bau gas tidak tercium lagi, dan tidak menjelaskan metode yang digunakan.

jika saat sensor mendeteksi adanya bau gas maka sistem mengaktifkan buzzer sebagai alarm peringatan dini akan adanya kebocoran gas yang terjadi. Selain itu, sistem ini juga dihubungkan dengan handphone, untuk memberi informasi bahwa kondisi gas telah berbahaya kepada pihak terkait serta tidak menjelaskan metode yang digunakan [5].

Sensor MQ6 digunakan sebagai sensor pendeteksi kebocoran liquified petrolium gas, kemudian peringatan tanda bahaya di kirimkan ke alarm, model ini merupakan hasil modifikasi untuk menggantikan sistem pendeteksi kebocoran gas yang telah terpasang di industri dan hotel dengan menjanjikan waktu respon yang cepat dan tidak menjelaskan metode yang digunakan [6].

Sensor MQ6 juga bisa diintegrasikan dengan microcontroller AT89C51. Dimana hasil dari pendeteksian yang diterima oleh sensor dikirimkan ke microcontroller untuk dikelola dan diproses untuk mengirimkan pesan peringatan ke berupa SMS, sensor digerakkan secara dinamis untuk mendeteksi kebocoran gas dan tidak menjelaskan metode yang digunakan [7].

Dalam penelitiannya [8] menyebutkan ATMega16 memroses jika sensor LDR yang diposisikan sebagai saklar dipicu oleh keberadaan kendaraan didekatnya maka timer dan counter diaktifkan, dan dalam penelitiannya tidak disebutkan metode yang digunakan.

\section{METODE PENELITIAN}

Jenis penelitian yang digunakan yaitu menggunakan penelitian eksperimen (eksperimental research) [9]. Sedangkan metode yang digunakan yaitu menggunakan metode 
software development life cyrcle, tampak pada Gambar 1. Tahapan-tahapan yang dilakukan dalam membangun sistem pendeteksi LPG ini, diantaranya :

a. Mengidentifikasi permasalahan yang terjadi selama ini di masyarakat akan seringnya terjadi ledakan yang diakibatkan oleh kebocoran gas. Hal ini terjadi dikarenakan tidak adanya sistem pendeteksi yang memeberikan peringatan dini dari kebocoran gas yang terjadi. Dari hasil pengamatan tersebut kemudian diidentifikasi kebutuhan perangkat keras dan perangkat lunak serta sistem notifikasi yang digunakan untuk membangun prototype sistem pendeteksi.

b. Dari tahap pertama yang sudah dijabarkan, kemudian di bangun alur data proses serta perancangan simulasi kerja antar perangkat yang akan digunakan oleh sistem pendeteksi LPG,

c. Kemudian di bangun prototype sistem pendeteksi kebocoran gas tersebut. Dengan menggunakan ATMega 16 sebagai pusat control, MQ6 sebagai sensor pendeteksi kebocoran gas, MQ5 sebagai sensor pendeteksian asap serta rotor DC sebagai penggerak baling-baling penghisap gas ke luar dari ruang kearea kebocoran agar bisa terurai dengan udara diluar ruangan dan bahasa $\mathrm{C}$ assembler sebagai algoritma pemrogramnya.

d. Dari prototype yang dibangun dan dirancang kemudian dilakukan serangkaian pengujian menggunakan blackbox testing untuk mendapatkan hasil kesempurnaan kerja dari tiap-tiap komponen di hadapan pengguna untuk mendapatkan feedback. Guna penyempurnaan sistem yang dibangun.

e. Dari feedback yang didapatkan dari pengguna kemudian dilakukan pengembangan ulang untuk mendapatkan sistem pendeteksi kebocoran gas yang sempurna.

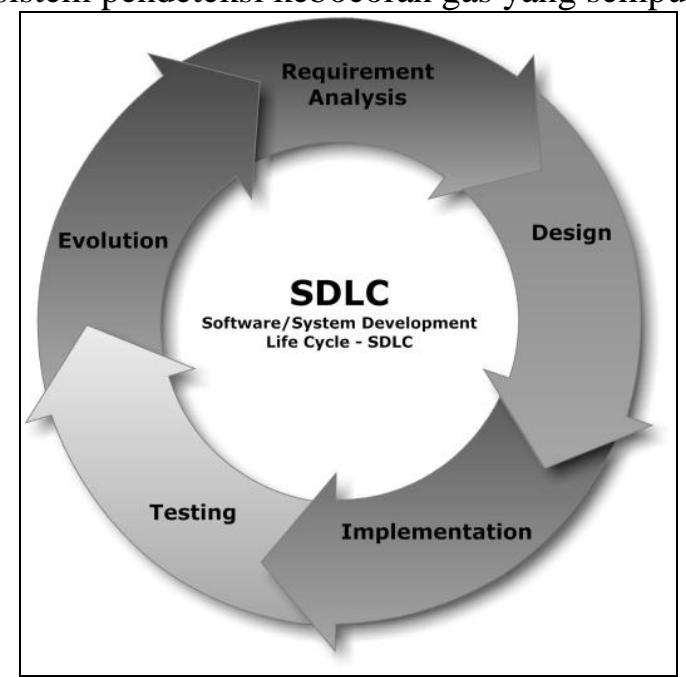

Gambar 1. Metode SDLC [9]

\section{HASIL DAN PEMBAHASAN}

1. Model Proses

Model proses yang digunakan dalam penelitian ini, digambarkan dalam bentuk flowchart, seperti yang diperlihatkan pada Gambar 2 dan Gambar 3. 


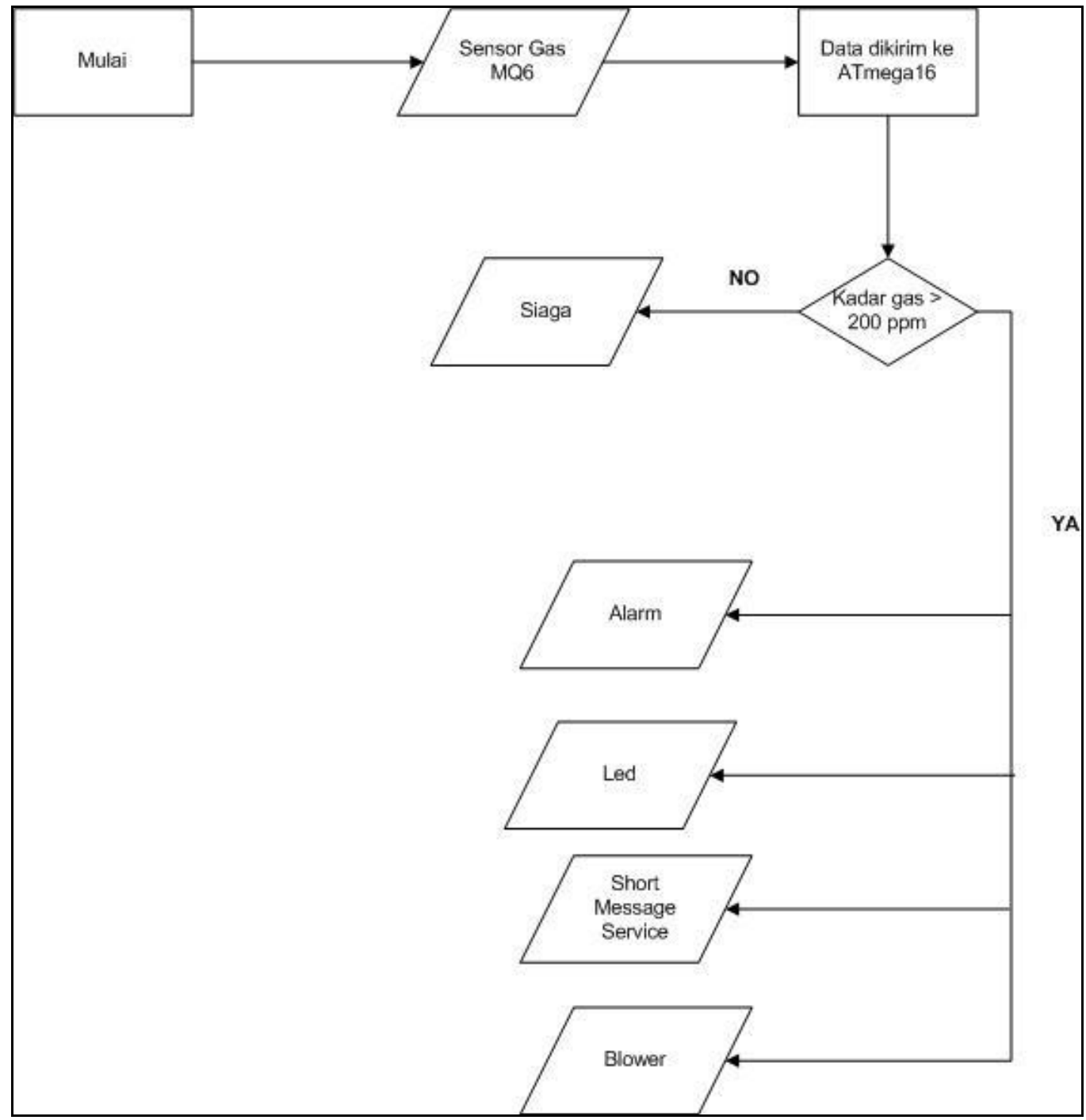

Gambar 2 Model proses kerja sistem deteksi kebocoran LPG

Uraian proses kerja pada gambar 2 adalah sebagai berikut :

1. Jika kebocoran LPG terdeteksi oleh sensor MQ6, maka signal-signal pulsa dikeluarkan dan dikirimkan ke Atmega16 untuk diolah.

2. Jika didapatkan jumlah kadar gas yang dideteksi oleh sensor sebesar $200 \mathrm{ppm}$ (part per million) atau lebih maka, Atmega 16 akan mengirimkan intruksi untuk membunyikan alarm dan lampu peringatan untuk mengingatkan orang-orang disekitar titik kebocoran bahwa ada kebocoran gas yang terjadi serta mengaktifkan kipas penghisap gas untuk di buang dari ruangan area kebocoran. Diwaktu yang bersamaan juga peringatan dikirimkan ke pemilik rumah atau orang-orang yang dituju oleh sistem sebagai notifikasi, jika si pemilik rumah tidak ada di tempat.

3. Jika kadar gas metan yang di deteksi oleh sensor MQ6 tidak sampai 200 ppm ataupun tidak terdeteksi adanya gas metan, maka sistem pendeteksi akan standby atau dalam posisi siaga. 


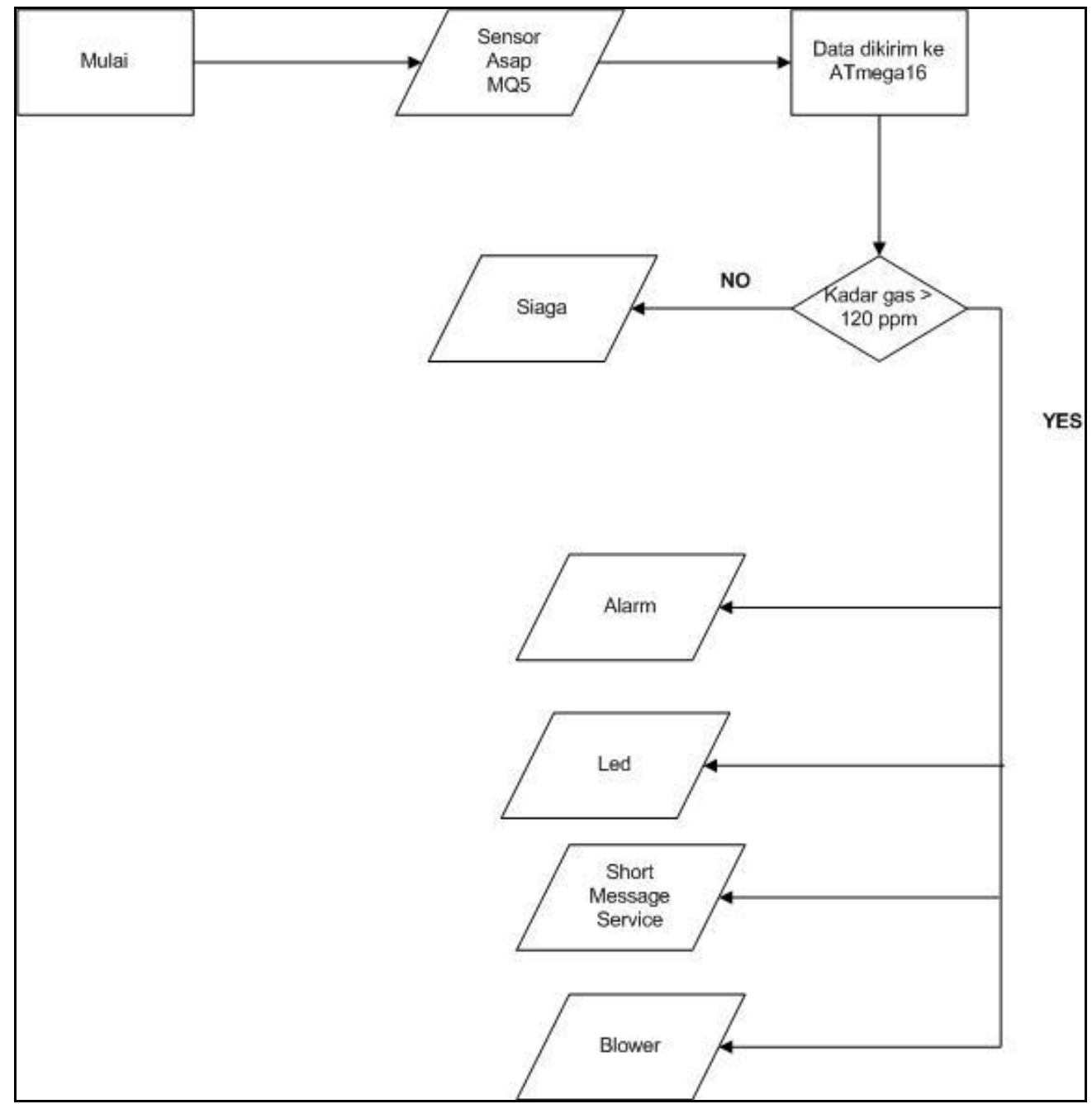

Gambar 3 Model proses kerja sistem deteksi asap kebakaran

Uraian proses kerja pada gambar 3 adalah sebagai berikut :

1. Pada saat asap dari indikasi adanya kebakaran terdeteksi oleh sensor MQ5, maka signal pulsa dari sensor akan dikirimkan ke ATmega16 untuk di olah.

2. Jika didapatkan kadar kepekatan asap yang dideteksi oleh sensor sebesar 120 ppm (part per million) atau lebih maka, Atmega 16 akan mengirimkan intruksi untuk membunyikan alarm dan lampu peringatan serta mengaktifkan kipas blower untuk menghisap asap keluar dari ruangan area kebocoran dan kebakaran. Diwaktu yang bersamaan juga peringatan dikirimkan ke pemilik rumah atau orang-orang yang dituju oleh sistem sebagai notifikasi, jika si pemilik rumah tidak ada di tempat.

3. Jika kadar kepekatan asap yang di deteksi oleh sensor MQ5 tidak sampai 120 ppm ataupun tidak terdeteksi adanya asap kebakaran, maka sistem pendeteksi akan standby atau dalam posisi siaga.

2. Arsitektur sistem

Adapun arsitektur sistem deteksi kebocoran LPG ini tampak pada Gambar 4, jika sistem deteksi mendapatkan kebocoran gas sebesar 200ppm, secara otomatis sistem akan mengirimkan pesan singkat ke pengguna sebagai notifikasi bahwa terjadi kebocoran gas, dan menghidupkan alarm serta lampu led sebagai notifikasi peringatan dini kepada pengguna di area sekitar titik kebocoran. 


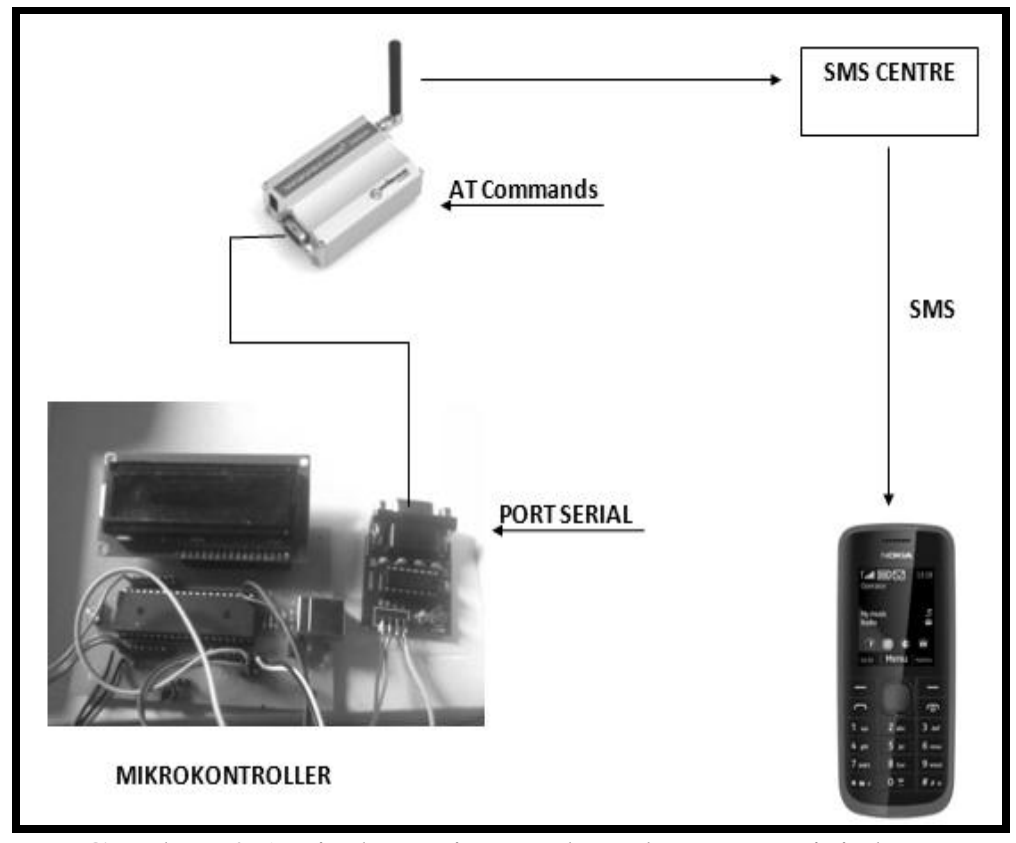

Gambar 4 Arsitektur sistem dan alur transmisi data.

Sistem pendeteksi kebocoran gas yang dibangun melibatkan Atmega 16, LCD display, serial port, buzzer, lampu LED, dan modem sebagai pengirim pesan singkat. MQ6 digunakan dikarenakan respon tanggap yang cepat terhadap gas metan, propana dan butana jika dibandingkan dengan sensor yang sejenis, buzzer digunakan sebagai alarm peringatan, lampu LED digunakan sebagai lampu peringatan dalam bentuk visualisasi tanda bahaya dan kipas blower diaktifkan untuk menghisap gas methan dan asap ke luar ruangan untuk mengurangi kadar asap dan gas dalam area kebocoran.

LCD display digunakan sebagai media display bahwa kadar gas terdeteksi sekian part per million (ppm), serial port digunakan sebagai port komunikasi penghubung antara ATmega16 dengan modem, modem digunakan sebagai pusat pengiriman pesan singkat.

Jika kebocoran gas sudah mencapai tingkat yang sudah ditentukan didalam program, maka pesan akan dikirmkan ke nomor yang dituju, kecepatan sampainya pesan ke nomor yang dituju tergantung oleh arsitektur jaringan selular masing-masing provider. Kelebihan sistem ini adalah bentuknya yang tidak terlalu besar.

\section{Teknik Pengujian dan Analisis Data.}

Teknik analisis data yang dilakukan dan gunakan dalam penlitian ini yaitu melakukan pengujian pada jarak dari sensor terhadap titik kebocoran untuk mendapatkan kecepatan respon sistem yang sangat baik dalam memberikan peringatan dini terhadap kebocoran gas yang terjadi.

Pengujian ini dilakukan sebanyak 5 kali dalam jarak yang berbeda yang dilakukan pada 2 tempat yang berbeda, yaitu ruang berfentilasi dan ruang kedap udara. Kemudian dari hasil pengujian tersebut dicatat dalam tabel pengujian mulai dari jarak pengujian waktu pengujian, waktu respon sistem terhadap kebocoran dan jumlah kadar LPG yang bocor dalam satuan ppm. Seperti tampak pada gambar 5 . 


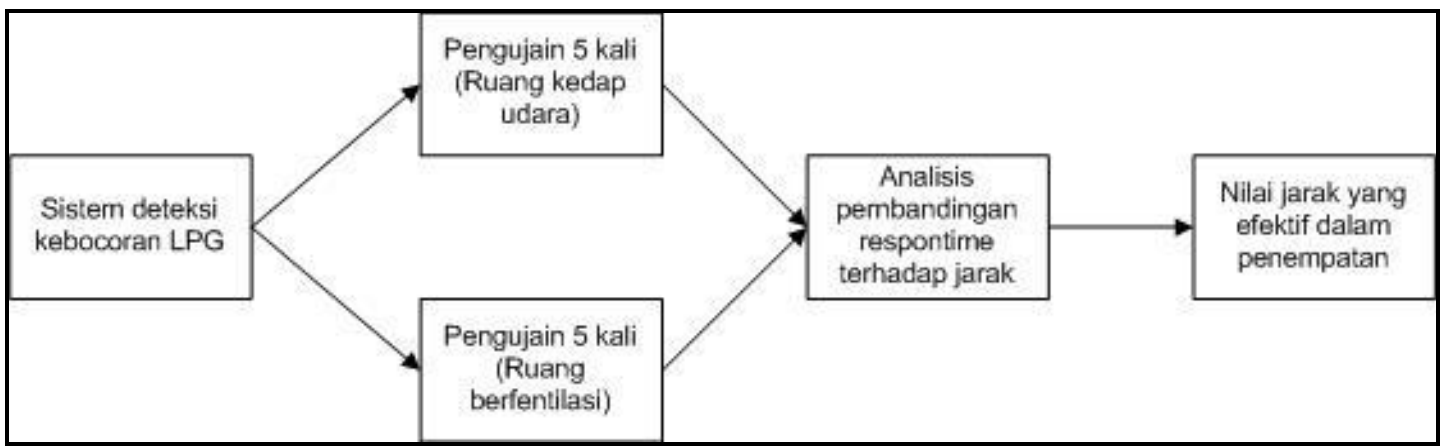

Gambar 5 Teknik Pengujian

Berdasarkan pengujian yang dilakukan terhadap sistem pendeteksi kebocoran LPG dan kebakaran, maka hasil pengujian tersebut disajikan dalam bentuk tabel dan grafik seperti tampak pada tabel 1 , tabel 2 , tabel 3 dan tabel 4 serta grafik perbandingan pada 2 ruangan yang berbeda tampak pada grafik 6 dan grafik 7 .

1. Pengujian diruang berfentilasi

Pengujian dilakukan sebanyak 5 kali dalam estimasi waktu pengujian selama 40 detik dan juga jarak yang berbeda, maka hasil pengujian yang didapatkan yaitu seperti yang disajikan pada tabel 1 berikut ini.

Tabel 1 Hasil pengujian sensor gas

\begin{tabular}{ccccc}
\hline No & Jarak & $\begin{array}{c}\text { Lama Waktu Pengujian } \\
\text { Gas }\end{array}$ & $\begin{array}{c}\text { Waktu Untuk } \\
\text { Mendeteksi }\end{array}$ & $\begin{array}{c}\text { Hasil Yang } \\
\text { Terdeteksi }\end{array}$ \\
\hline 1 & 2,5 Meter & 40 Detik & 32 Detik & $136 \mathrm{ppm}$ \\
\hline 2 & 2 Meter & 40 Detik & 40 Detik & $93 \mathrm{ppm}$ \\
\hline 3 & $1,5 \mathrm{Meter}$ & 40 Detik & 45 Detik & $106 \mathrm{ppm}$ \\
\hline 4 & 1 Meter & 40 Detik & 32 Detik & $319 \mathrm{ppm}$ \\
\hline 5 & 0,5 Meter & 40 Detik & 10 Detik & $555 \mathrm{ppm}$ \\
\hline
\end{tabular}

Sumber: diolah sendiri

Dari hasil pengujian yang ditampilkan pada tabel 1 bahwa selama pengujian 40 detik dimana jarak antara objek kebocoran dan alat deteksi relatif terbatas didapatkan waktu deteksi yang berbeda dan jumlah kumpulan gas yang terdeteksi oleh sensor berbeda-beda.

Pada jarak 1,5 meter didapatkan waktu deteksi 45 detik dengan jumlah kadar gas yang terdeteksi sebesar 106ppm, jumlah kadar gas yang didapatkan jauh lebih kecil jika di bandingkan dengan pengujian pada jarak 2,5 meter dimana kadar gas yang di dapatkan sebesar 136 ppm dengan waktu deteksi 32 detik selama pengujian 40 detik.

Hal ini bisa saja disebabkan sirkulasi udara yang berada pada lokasi pengujian, udara yang masuk kedalam ruangan pada saat pengujian jarak 1,5 meter membuat kepekatan gas metan tersamarkan dan terurai sehingga sensor hanya mendapatkan nilai kepekatan gas 106 ppm dan membuat waktu pendeteksian sensor lebih besar dari pengujian jarak 2.5 meter. Tetapi nilai kepekatan gas yang terdeteksi masih dikatakan aman oleh sistem karena nilai kepekatan gas kurang dari 200 ppm

Table 2 Hasil pengujian sensor asap

\begin{tabular}{ccccc}
\hline No & Jarak & $\begin{array}{c}\text { Lama Waktu Pengujian } \\
\text { Asap }\end{array}$ & $\begin{array}{c}\text { Waktu Untuk } \\
\text { Mendeteksi }\end{array}$ & $\begin{array}{c}\text { Hasil Yang } \\
\text { Terdeteksi }\end{array}$ \\
\hline 1 & 2,5 Meter & 40 detik & 120 Detik & $43 \mathrm{ppm}$ \\
\hline 2 & 2 Meter & 40 detik & 45 Detik & $46 \mathrm{ppm}$ \\
\hline 3 & 1,5 Meter & 40 detik & 30 Detik & $50 \mathrm{ppm}$ \\
\hline 4 & 1 Meter & 40 detik & 25 Detik & $58 \mathrm{ppm}$ \\
\hline 5 & 0,5 Meter & 40 detik & 15 Detik & $224 \mathrm{ppm}$ \\
\hline
\end{tabular}

Sumber : diolah sendiri

Dari hasil pengujian yang ditampilkan pada tabel 2 bahwa selama pengujian 40 detik dimana jarak antara objek kebakaran dan alat deteksi terbatas didapatkan waktu deteksi dan 
kadar kepekatan asap yang berbeda. Semakin jauh alat deteksi dengan jarak pusat kebakaran maka kadar asap yang terdeteksi tidak terlalu pekat, maka sistem tidak akan mengaktifkan notifikasi peringatan dini dan waktu yang dibutuhkan oleh sensor untuk mendeteksi kadar asap pada suatu ruangan akan butuh waktu lebih lama.

Pada jarak 2,5 meter waktu yang dibutuhkan lebih lama untuk mendeteksi adanya kebakaran walaupun waktu pengujian hanya di batasi 40 detik pengujian. Artinya sensor melebihi lamanya waktu pengujian baru bisa mendeteksi kadar asap. Berbeda dengan jarak 0,5 meter waktu deteksi lebih cepat dengan kadar kepekatan asap jauh lebih besar dari jarak 2,5 walapun lama waktu pengujian adalah 40 detik.

Hal ini difaktorkan jarak yanng jauh dari tiap-tiap pengujian, jarak yang jauh dapat memungkinkan asap terurai bersama udara yang melintasi suatu ruangan sehingga sensor sedikit mengalami kesulitan dalam melakukan pendeteksian asap. Karena asap bukanlah suatu media dan zat statis, ia akan terurai begitu terbawa udara.

\section{Pengujian di ruang kedap udara}

Sama seperti pada pengujian diruang berfentilasi, pengujian sebanyak 5 kali pada estimasi waktu 40 detik dan jarak pengujian yang berbeda, maka hasil pengujian yang didapatkan yaitu seperti yang disajikan pada tabel 3 berikut ini.

Tabel 3 hasil pengujian sensor gas

\begin{tabular}{ccccc}
\hline No & Jarak & $\begin{array}{c}\text { Lama Waktu Pengujian } \\
\text { Gas }\end{array}$ & $\begin{array}{c}\text { Waktu Untuk } \\
\text { Mendeteksi }\end{array}$ & $\begin{array}{c}\text { Hasil Yang } \\
\text { Terdeteksi }\end{array}$ \\
\hline 1 & 2,5 Meter & 40 Detik & 25 Detik & $94 \mathrm{ppm}$ \\
\hline 2 & 2 Meter & 40 Detik & 20 Detik & $96 \mathrm{ppm}$ \\
\hline 3 & 1,5 Meter & 40 Detik & 15 Detik & $402 \mathrm{ppm}$ \\
\hline 4 & 1 Meter & 40 Detik & 13 Detik & $543 \mathrm{ppm}$ \\
\hline 5 & 0,5 Meter & 40 Detik & 10 Detik & $580 \mathrm{ppm}$ \\
\hline
\end{tabular}

Sumber : diolah sendiri

Hasil yang ditampilkan pada tabel 3 dimana lama pengujian selama 40 detik dan jarak Antara objek kebocoran dan sistem pendeteksi relatif terbatas didapatkan waktu deteksi yang berbeda dan jumlah kumpulan gas yang terdeteksi oleh sensor berbeda.

Seperti yang diperlihatkan pada perbandingan pengujian pada jarak 2,5 meter dan jarak 1,5 meter dimana kepekatan yang dihasilkan pada jarak 1,5 meter sebesar 402 ppm lebih besar dengan waktu deteksi sebesar 15 detik dari pengujian pada jarak 2,5 meter sebesar 94 ppm dengan waktu yang dibutuhkan sebesar 15 detik.

Hal ini bisa saja disebabkan oleh sirkulasi udara yang tidak dihasilkan pada pengujian diruang tertutup tanpa ventilasi.

Tabel 4 Hasil pengujian sensor asap

\begin{tabular}{ccccc}
\hline No & Jarak & $\begin{array}{c}\text { Lama Waktu Pengujian } \\
\text { Asap }\end{array}$ & $\begin{array}{c}\text { Waktu Untuk } \\
\text { Mendeteksi }\end{array}$ & $\begin{array}{c}\text { Hasil Yang } \\
\text { Terdeteksi }\end{array}$ \\
\hline 1 & 2,5 Meter & 40 Detik & 30 Detik & $85 \mathrm{ppm}$ \\
\hline 2 & 2 Meter & 40 Detik & 20 Detik & $91 \mathrm{ppm}$ \\
\hline 3 & 1,5 Meter & 40 Detik & 19 Detik & $102 \mathrm{ppm}$ \\
\hline 4 & 1 Meter & 40 Detik & 15 Detik & $115 \mathrm{ppm}$ \\
\hline 5 & 0,5 meter & 40 Detik & 13 Detik & $174 \mathrm{ppm}$ \\
\hline & Sumber diolah sendiri & & &
\end{tabular}

Hasil pengujian yang dilakukan pada sensor asap kebakaran yang disajikan dalam tabel 4 di ruang tertutup. Didapatkan bahwa pada pengujian di jarak 2,5 meter waktu yang dibutuhkan oleh sensor untuk mendeteksi kadar asap adalah 30 detik dengan jumlah kepekatan asap sebesar $85 \mathrm{ppm}$. 
Hasil yang berbeda diperlihatkan pada pengujian di jarak 1,5 meter dimana waktu yang dibutuhkan oleh sensor untuk melakukan pendeteksian adalah setengah dari waktu yang dibutuhkan oleh sensor pada saat pengujian di jarak 2,5, dimana kadar kepekatan asap yang di deteksi oleh sensor adalah $102 \mathrm{ppm}$ pada pengujian 1,5 meter.

Hasil yang jauh berbeda diperlihatkan pada pengujian 0, 5 meter dimana di lama waktu pengujian yang sama waktu yang dibutuhkan sensor untuk mendeteksi kadar asap hampir setengah waktu yang dibutuhkan oleh sensor pada pengujian jarak 2,5 meter dengan kadar kepekatan asap yang dideteksi 2 kali lipat pada pengujian di jarak 2,5 meter yaitu 175 ppm.

Perbedaan hasil pengujian tersebut tidak mempengaruhi lamanya waktu pengujian, hasil akan dapat segera dihasilkan dari kadar asap yang diterima oleh sensor, semakin jauh jarak pusat kebakaran dengan sensor. Maka akan semakin lama waktu yang diperlukan oleh sensor dan semakin bias kadar asap yang melintas di sensor.

Hal ini bisa juga disebabkan oleh udara yang melintas atau memasuki suatu ruangan, karena asap merupakan zat dinamis yang dapat memasuki suatu media ruang.

Dari hasil pengujian tersebut kemudian disajikan dalam bentuk grafik perbandingan pengujian sistem kebocoran LPG antara ruang berfentilasi dan ruang kedap udara. Seperti tampak pada gambar 6.

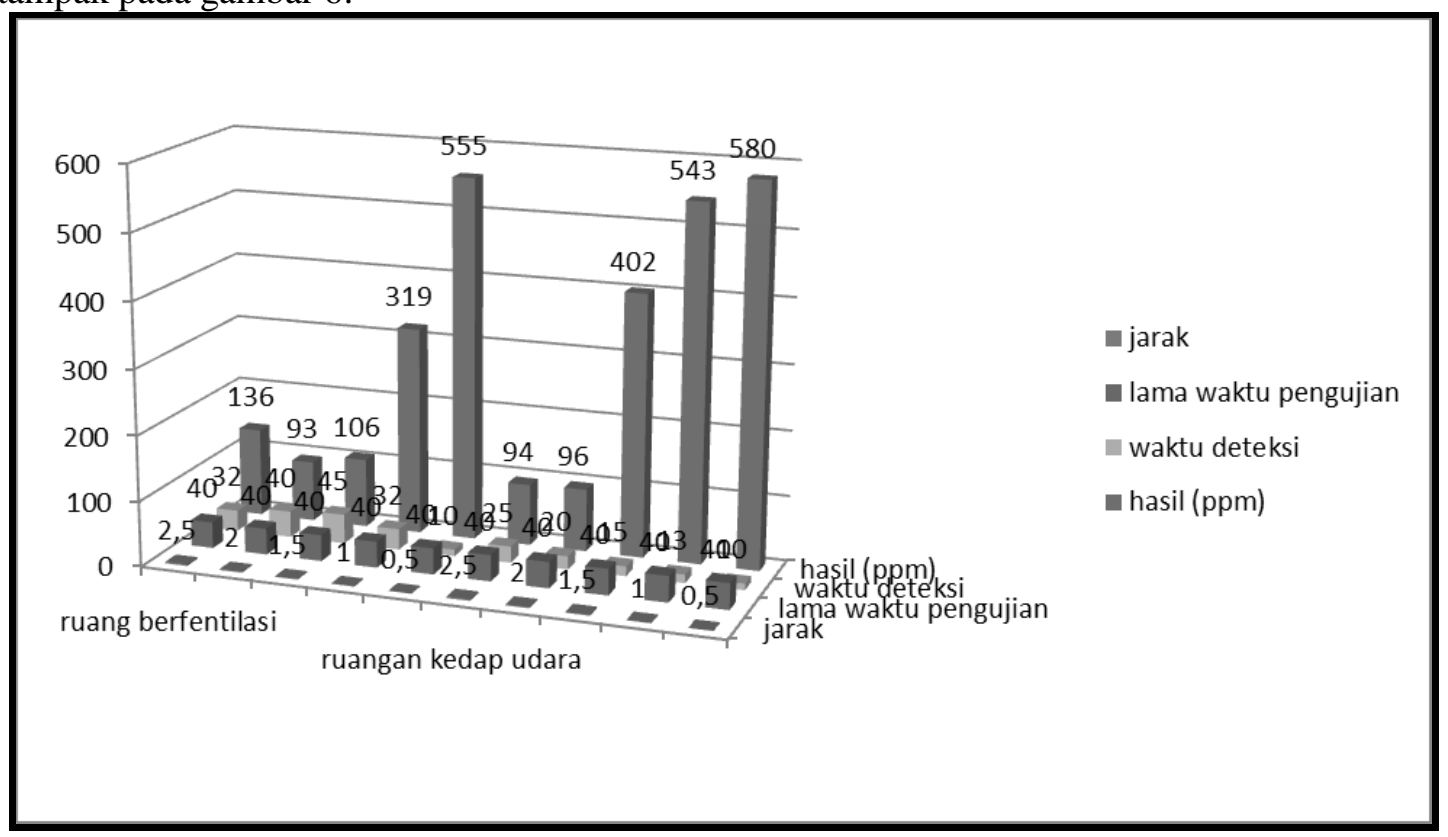

Gambar 6 Perbandingan Sensor pendeteksi kebocoran pada 2 ruang berbeda

Gambar 6, dapat dijelaskan jika jarak antara alat dan objek yang disensor sangat mempengaruhi alat dalam melakukan pendeteksian. Semakin dekat jarak antara alat dan objek yang disensor dan sirkulasi udara yang kecil, maka akan semakin cepat pula sistem akan mendeteksi jika terjadi kebocoran gas sehingga sangat efisien untuk mencegah terjadinya kecelakaan kebakaran.

Jarak yang ideal dalam melakukan pendeteksian antara 0,5 meter - 1 meter. Kemudian faktor lain yang mempengaruhi penyensoran adalah faktor angin, jika angin yang berhembus cukup kencang maka kadar gas maupun asap yang terdeteksi akan berkurang.

Hasil pengujian sensor asap kebakaran kemudian disajikan dalam bentuk grafik perbandingan pengujian sistem kebocoran LPG antara ruang berfentilasi dan ruang kedap udara pada Gambar 7. 


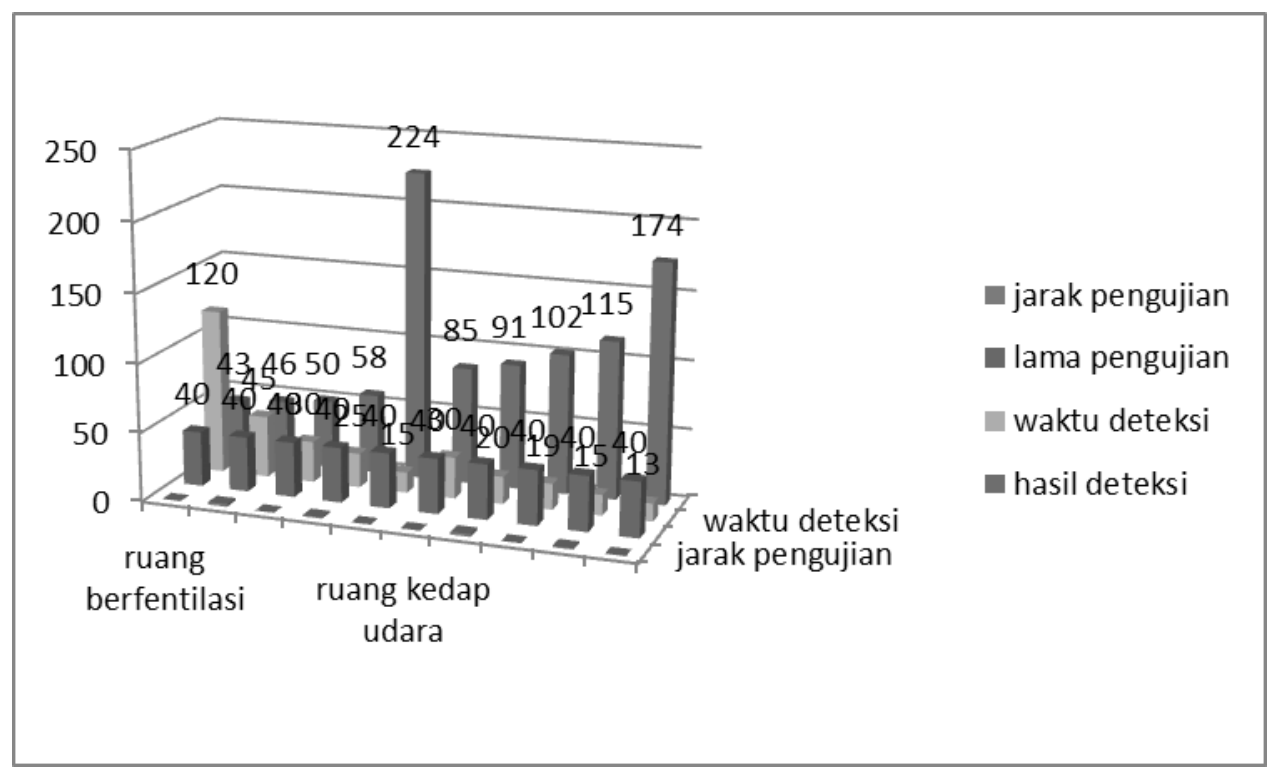

Gambar 7 Perbandingan sensor asap pada 2 tipe ruangan yang berbeda

Gambar 7 dapat dijelaskan bahwa lamanya waktu yang dibutuhkan oleh sensor akan sangat jauh berbeda ini di sebabkan oleh jarak antara pusat kebakaran dengan sistem deteksi kebakaran, jarak yang jauh bisa menyebabkan kepekatan asap yang melintas atau berada di sekitar sensor bisa terbiaskan atau terurai dengan udara yang melintas dalam suatu ruangan atau bisa saja waktu deteksi lebih cepat pada ruang berfentilasi karena asap yang dihasilkan pada situasi kebakara tertiup angin yang searah dengan sensor di bandingkan dengan pengujian di ruang tertutup.

\section{KESIMPULAN}

Simpulan yang dapat diambil dalam pengujian sistem pendeteksi liquified petrolium gas ini, diantaranya :

1. Dari hasil analisa dan pengujian yang didapatkan pada saat simulasi, sistem pendeteksi kebocoran gas dan pendeteksi asap kebakaran yang di bangun dapat bekerja dengan baik dan seluruh notifikasi dikirimkan dengan sangat baik menggunakan alarm peringatan maupun menggunakan pesan singkat yang dikirimkan ke pemilik rumah sehingga dampak kecelakaan kebakaran dapat di cegah dan berkurangnya kerugian baik materi dan korban jiwa.

2. Selama melakukan pengujian didapatkan hasil reaksi yang sangat baik dimana sistem dapat memberikan reaksi kurang dari 1 menit.

3. Kecepatan waktu pendeteksian dan kepekatan partikel gas dan kepekatan asap hasil kebakaran yang terdeteksi oleh sensor MQ6 dan MQ5 bisa sebabkan oleh sisrkulasi udara yang masuk ke dalam ruangan dimana objek kebocoran gas terjadi.

4. Sistem yang di bangun hanya bersifat peringatan bukan sebagai sistem pengendalian terhadapat kebocoran.

5. Dari sisi sumber daya yang digunakan masih menggunakan sumber daya yang masih terhubung langsung ke listrik utama bukan menggunakan sumber daya listrik portable. Jika terjadi pemadaman listrik, maka sistem pendeteksi ini akan ikut padam dan tidak berfungsi. Maka perlu dilakukan penyempurnaan dari sisi sumber daya.

6. Pesan singkat akan terkirim jika pulsa yang terdapat pada sim card memiliki nominal pulsa yang mencukupi, jika nominal pulsa pada sim card tidak mencukupi, maka pesan singkat yang berisi pemberitahuan kebocoran gas tidak akan pernah sampai ke nomor yang dituju. 


\section{SARAN}

Dalam penerapan teknologi ini masih banyak kekurangan khususnya sistem power yang hanya menggunakan 1 prinsip kelistrikan (koneksi kelistrikan tunggal ke instalasi PLN), kemudian di sisi instalasi komponen yang masih dalam bentuk prototipe dan keterbatasan sensor yang digunakan. Diharapkan pada penelitian selanjutnya bisa menyemputnakan teknologi yang digunakan seperti terhubung ke sistem terpusat dengan memutus aliran listrik dan mengaktifkan sistem pendinginan yang ada pada area tersebut sehingga ledakan dan kebakaran yang diakibatkan oleh kebocoran gas ini bisa di minimalisir

\section{UCAPAN TERIMA KASIH}

Penulis mengucapkan terima kasih kepada STMIK PALCOMTECH Palembang yang telah memberi dukungan financial terhadap penelitian ini.

\section{DAFTAR PUSTAKA}

[1] Rosmayati, Lisna. 2012. Kajian Komposisi Hidrokarbon dan Sifat Fisika-Kimia LPG untuk Rumah Tangga. Lembaran Publikasi Minyak dan Gas Bumi, Vol.46 No.2.

[2] Patrizki, Ismar. (2010). 2010 Ini, 78 Kasus Ledakan Tabung Gas Terjadi. Tersedia dalam: http:// http://metro.news.viva.co.id/news/read/163235-2010-ini--78-kasus-ledakan-tabunggas-terjadi(diakses 12 Januari 2015).

[3] Mulia, Prima. (2014). Tabung Gas Melon Meledak, 12 Anak Kritis . Tersedia dalam: http:// http://www.tempo.co/read/news/2014/07/23/064595217/Tabung-Gas-Melon-Meledak-12Anak-Kritis(diakses 12 Januari 2015)

[4] Fauziah dan Muhammad Subali. 2012. Alat Pendeteksi Otomatis Kebocaoran Gas LPG Berbasiskan ATMega8535. Seminar Nasional Teknologi Informasi (SNATI).

[5] Saefullah, asep et.al. 2012. Pendeteksi Kebocoran Tabung Gas lpg Menggunakan Mikrokontroller AT89s2051Melalui Handphone Sebagai Media Informasi. Seminar Nasional Teknologi Informasi \& Komunikasi Terapan (Semantik).

[6] Shinde, Sagar et.al. 2012. Development of Movable Gas Tanker Leakage Detection Using Wireless Sensor Network Based on Embedded System. International Journal of Engineering Research and Applications (IJERA), Vol.2, Issue 6.

[7] Shrivastava, Ashish et al. (2013). Gsm based gas leakage Detection system. International Journal of Technical Research and Applications (IJTRA). Vol. 1, No. 2 p. 42-45

[8] Vrileuis, Adam. 2013. Pemantau Lalu Lintas dengan Sensor LDR Berbasis Mikrokontroler ATmega16. Jurnal Rekayasa Elektrika Vol. 10, No. 3.

[9] A.S Rossa dan Shalahudin, M. 2011. Modul pembelajaran rekayasa perangkat lunak terstruktur dan berorientasi objek. Modula: bandung 